Поляєв А. І.

\title{
Деякі аспекти впровадження оборонного менеджменту в оборонних відомствах держав-членів НАТО
}

Центр воєнно-стратегічних досліджень Національного університету оборони України імені Івана Черняховського, Київ

Резюме. У статті проведено аналіз аспектів упровадження оборонного менеджменту в національних оборонних відомствах держав-членів і партнерів Свроатлантичного альянсу.

Ключові слова: оборонний менеджмент; спроможності; оборонне планування; оборонні процеси; бюджетне планування; НАТО.

Постановка наукового завдання. Однією 3 оперативних цілей оборонної реформи в Україні визначено “впровадження процесу оборонного менеджменту у сфері оборони відповідно до євроатлантичних принципів та підходів” $[1,2]$.

Для успішної реалізації зазначеної оперативної цілі необхідне досконале вивчення досвіду держав-членів НАТО щодо розвитку оборонного менеджменту i його впровадження в Міністерстві оборони України.

Аналіз останніх наукових досліджень і публікацій підтверджує, що зазначена проблематика в оборонних відомствах держав-членів Альянсу та України на сьогодні активно досліджується. Вивченню процесів оборонного менеджменту у державахчленах НАТО присвячена значна кількість наукових праць та аналітичних документів оборонного планування. Цим питанням активно займаються провідні вітчизняні вчені й практики у сфері стратегічного та оборонного менеджменту: А. Петренко [3], О. Шаталова [5], В. Полікашин [8], Ф. Саганюк [9] та інші. Водночас в опублікованих працях недостатньо уваги приділяється питанням розроблення методології оборонного менеджменту та впровадження iï в оборонних відомствах держав-членів Альянсу відповідно до вимог стандартів НАТО.

Метою статті $\epsilon$ аналіз особливостей впровадження оборонного менеджменту, що застосовується в оборонних відомствах держав-членів НАТО.

Виклад основного матеріалу. Аналіз генезису впровадження менеджменту в бізнесструктурах i в державному управлінні підтверджує, що оборонний менеджмент виник нещодавно як тема, що становить інтерес для сектору безпеки і оборони.

Згодом окремі держави-члени НАТО розпочали поступове впровадження процедур оборонного менеджменту у процесі вирішення оборонних проблем, зокрема, таких як розподіл фінансових i людських ресурсів, вирішення стратегічних та оперативних завдань, 3 використанням притаманних бізнесу інструментів для управління в оборонному секторі.

Цей підхід потребує забезпечення розвитку спроможностей на всіх рівнях i в кожному підрозділі міністерства оборони країни. Одним із перевірених способів досягнення цього $\epsilon$ використання його, насамперед, у тих сегментах оборонної організації, які можуть сприяти максимальній ефективності оперативної діяльності збройних сил.

Зважаючи на важливість цивільного i демократичного контролю за збройними силами та формуваннями безпеки, на Стамбульському саміті НАТО в червні 2004 року главами держав і урядів 49-ти держав-членів і партнерів НАТО був ухвалений План дій щодо партнерства 3 розбудови оборонних інституцій (Partnership Action Planon DefenceInstitution Building (PAPDIB) 2004) [7].

План дій партнерства 3 розбудови оборонних інституцій (PAP-DIB) передбачав посилення дії країн-партнерів з реформування і реструктуризації своїх оборонних інституцій, які задовольняли б як національні потреби, так і міжнародні зобов'язання цих країн.

Серед основних цілей Плану дій були,зокрема, такі:

дієві та прозорі механізми демократичного контролю над оборонною діяльністю;

участь цивільних урядовців у розробленні політики оборони і безпеки; дієвий i прозорий законодавчий i судовий нагляд за сектором безпеки; 
поглиблене оцінювання ризиків для безпеки i національних оборонних потреб, узгоджене із забезпеченням i утриманням оперативно сумісних i економічно виправданих сил і засобів;

оптимізація менеджменту в

міністерствах оборони та інших відповідних відомствах, які мають у своєму розпорядженні збройні формування;

дотримання міжнародних норм i стандартів в оборонному секторі, зокрема щодо контролю за експортом;

ефективні та прозорі процедури розміщення фінансових, матеріальних ресурсів, планування в оборонній сфері;

ефективне управління оборонними

видатками та соціально-економічними

наслідками реструктуризації оборонного

відомства;

ефективні та прозорі кадрові структури в збройних силах;

дієва міжнародна співпраця i добросусідські відносини 3 питань оборони і безпеки.

3 урахуванням національної специфіки окремі держави-члени НАТО надають перевагу створенню нових органів управління або рад оборонного менеджменту 3 відповідним статусом і переліком повноважень. В інших державах не проводиться інституційний розподіл між організаційними структурами та менеджерськими завданнями. Так, наприклад, у Великій Британії оборонний менеджмент перебуває у компетенції Ради оборонного менеджменту при Раді оборони [4]. У Сполучених Штатах Америки є тільки Рада оборонного менеджменту [4]. У Франції оборонний менеджмент здійснюється двома комітетами міністерства оборони - комітетом 3 оборонних інвестицій, очолюваним міністром оборони, та фінансовим комітетом, який займається бюджетними питаннями. Проте за будь-яких організаційних особливостей оборонний менеджмент у більшості держав-членів НАТО є законодавчо врегульованим, 3 визначеною мірою відповідальності цивільних і військових менеджерів всіх рівнів [5].

На сьогодні в країнах Альянсу користуються поняття оборонного менеджменту як процесом вирішення таких питань, як виділення фінансових чи людських ресурсів, вирішення стратегічних та оперативних проблем у рамках комплексного підходу або використання притаманних бізнесу інструментів для управління в оборонному секторі.

Таким чином оборонний менеджмент розглядатися як системний процес планування, організації та забезпечення, керівництва та контролю в оборонному відомстві для досягнення конкретної спільної (інституційної) мети [4].

Дослідження Террі Макконвіля та Річарда Холмса показують, що у сфері оборони, як і в кожній іншій сфері, процес менеджменту здійснюється на всіх рівнях організації i регулює весь спектр організаційної діяльності [6]. Цей процес починається 3 формулювання політики на найвищому рівні керівництва (командування) і поширюється на нижчі рівні керівництва та контроль, іноді аж до найдрібніших деталей, у всіх аспектах діяльності. Відповідно, керівники мають належним чином оцінити ситуацію для планування, організації, управління, координації та контролю зусиль своїх організацій (структур, підрозділів).

Як організаційний процес, оборонний менеджмент перебуває між формуванням політики оборони і фактичним управлінням збройними силами. Цей процес має охоплювати такі сфери, як управління оборонними ресурсами, управління персоналом і управління закупівлями.

Розвиток спроможностей сектору безпеки i оборони - ще одне ключове завдання, яким займаються уряди державчленів Євроатлантичного альянсу протягом принаймні останнього десятиліття. Окремі країни зосереджуються на трансформації своїх збройних сил 3 метою підвищення ефективності реагування на нові проблеми безпеки століття, а інші домагаються більш масштабної перебудови всієї сфери оборони задля створення нових оборонних інституцій, особливо ті країни, які нещодавно перейшли на демократичний шлях, або все ще перебувають на завершальній стадії цього переходу. Усі ці держави мають стратегічні цілі (завдання) щодо реформування сектору безпеки i оборони, визнаючи успіх цих реформ як фактор, що сприяє інтеграції 3 євроатлантичним співтовариством та зміцненню безпеки та добробуту їх громадян.

Оборонний менеджмент зорієнтований на підвищення ефективності оборонного відомства, а відповідно - на створення нових спроможностей сил оборони і більш широких можливостей для виконання ними своїх зобов'язань із забезпечення державної безпеки та ефективного захисту від зовнішніх загроз. 
Завдяки тому, що ресурси витрачаються відповідально та стратегічно правильно, відповідно до визначеної політики національної безпеки, оборонний менеджмент сприяє ефективному управлінню. Це потребує суворого дотримання прозорості та підзвітності на всіх організаційних рівнях та наявності ефективної системи контролю.

y багатьох країнах державна адміністрація заміняе свою досить негнучку і бюрократичну форму роботи від імені суспільства на більш гнучкий і підзвітний менеджмент публічного сектору. Тоді виникає питання, а яким чином, аналогічно, уряд може підвищувати ефективність управління в оборонній сфері та "зміцнювати оборону". Частина відповіді полягає у введенні менеджерської практики з бізнесового сектору у сферу оборони, де досягнення очікуваних результатів в умовах конкурентного середовища має першорядне значення для виживання будь-якої організації [4].

У системі оборонного менеджменту планування відрізняється від планування військової операції та має прямий вплив на розвиток спроможностей збройних сил за допомогою придбання новітніх зразків озброєння та військової техніки. Крім того, у менеджерському сенсі організаційна діяльність передбачає привнесення гнучкості у жорсткі структури шляхом організації робочих процесів у рамках цих структур, а не реорганізації самої структури. Зі свого боку, лідерство означає як взяття на себе відповідальності за прийняття рішення, так i делегування елементів процесу прийняття рішень, що відрізняється від добре сформованої системи підлеглості (субординаціï) у збройних силах. Контроль за виконанням прийнятих рішень, в основному, означає відстеження подій і втручання, за необхідності, щодо переорієнтації сил i засобів на інші завдання.

3 іншого боку, оборонний менеджмент не заміняе і не може замінити специфічні військові процеси планування та проведення військових операцій і підтримання бойової готовності. Основним завданням оборонного менеджменту є об'єднання людей в рамках оборонних організацій 3 підготовкою, озброєнням i військовою технікою, та із всебічним забезпеченням збройних сил для кращого виконання стратегічних оборонних завдань. \begin{tabular}{lllr}
\multicolumn{2}{c}{ Оборонний } & \multicolumn{2}{c}{ менеджмент може } \\
розглядатися & \multicolumn{1}{c}{ процес планування, } \\
організації & та забезпечення кадрами, \\
керівництва & та контролю над діяльністю \\
всередині & оборонної організації на
\end{tabular} систематичній основі для досягнення конкретної загальної (відомчої) цілі.

Оборонний менеджмент $\epsilon$ одночасно науковим методом і мистецтвом розширення прав i можливостей людей. Він робить організацію більш ефективною і економічною, ніж без менеджменту і менеджерів (включаючи міністрів, директорів, командирів тощо).

Загальними менеджерськими функціями оборонного менеджменту $\epsilon$ : планування, організація, керівництво та контроль.

Планування є вибором і послідовним визначенням завдань, які потрібно виконати для досягнення організаційної мети. Плани можуть бути стратегічними, довгостроковими або короткостроковими, загальними або на випадок певних ситуацій. План пояснює ціль i підходи (стратегії, політики, принципи) і є основою для прийняття рішень 3 питань організації та забезпечення.

Організація цे комплектування $\epsilon$ діяльністю 3 координації ролей, завдань та обов'язків підрозділів, а також розподілу необхідних ресурсів між ними для досягнення бажаної мети у визначений час. Сюди входить процес залучення, добору, підготовки, розміщення та підвищення кваліфікації особового складу відповідно до визначених ролей і завдань. Якість персоналу та підходи до його організації визначають стиль керівництва.

Керівництво є виконанням функцій мотивації, лідерства та впливу стосовно підлеглих на шляху до досягнення спільної мети. Керівництво вимагає організаційного чуття та вміння, а також лідерських якостей для мотивації послідовників за допомогою створення сприятливої робочої атмосфери. Керівництво може бути ефективним на всьому шляху до досягнення спільної мети, якщо воно супроводжується систематичним моніторингом і контролем.

Моніторинг $i$ контроль є діяльністю менеджера щодо забезпечення ситуації, коли всі його/іiі підрозділи упорядковано рухаються у напрямі до цілі. Іншими словами, контроль потрібен для того, щоб у ситуації, коли успіх підрозділу у виконанні його завдання залежить від вжиття заходів іншим підрозділом, вони були вжиті [4]. 


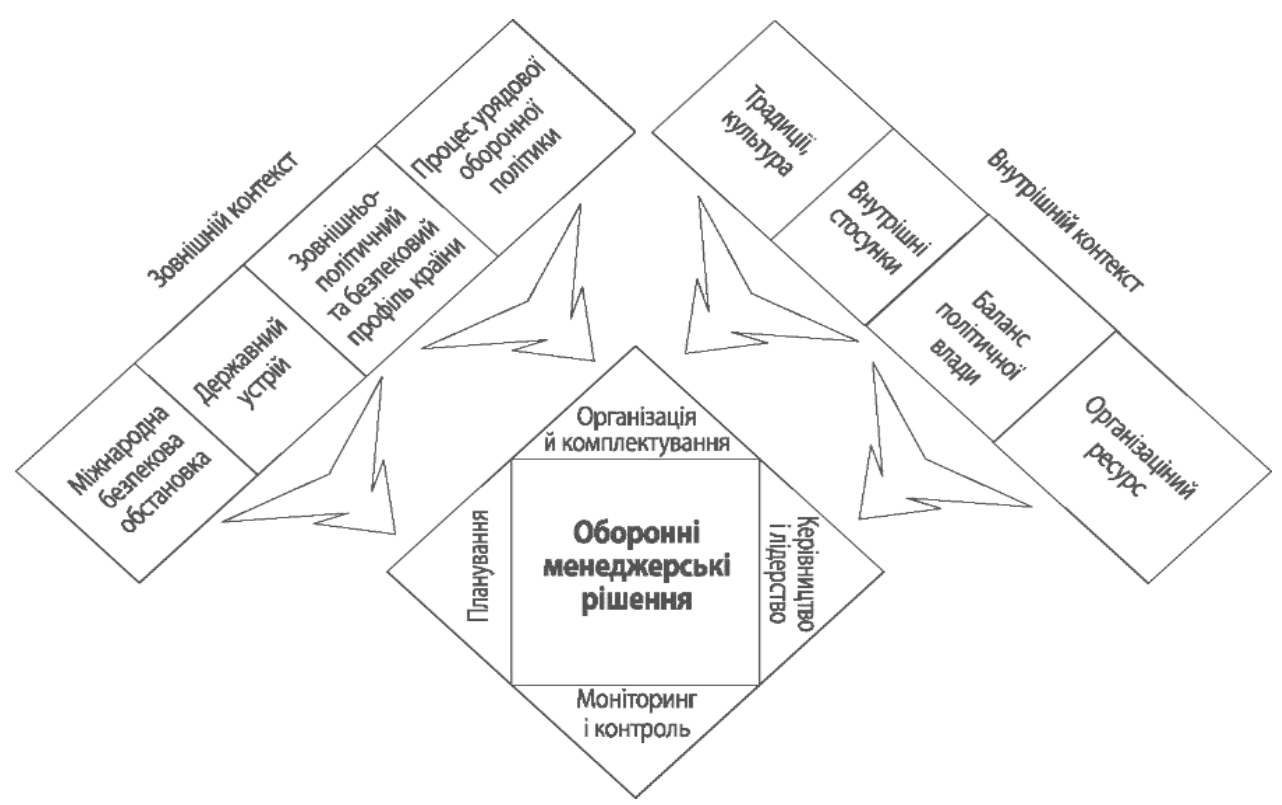

Рис. 1. Елементи циклу оборонного менеджменту в контексті внутрішнього та зовнішнього впливу

Оборонний менеджмент має

циклічний характер. Основні елементи циклу оборонного менеджменту наведено на рис. 1.

Оборонний менеджмент використовує певний набір методів роботи: аналізи;

оперативний, системний i структурний

планування та програмування;

моделювання та симуляція;

створення альтернатив;

оцінювання результатів і удосконалення процесу;

управління проєктами;

оцінювання ризиків;

інші методи i прийоми, які застосовуються під час формування та реалізації оборонної політики.

Незалежно від того, яка вертикаль обговорюється і на якій стадії, оборонний менеджмент у державах-членах НАТО розглядається в більш широких межах політики національної безпеки на основі конкретного контексту, 3 урахуванням конкретних обставин i відповідно до міжнародних стандартів ефективного управління [4]. Іншими словами, мають бути встановлені конкретні цілі, основані на реальних потребах у сфері безпеки і оборони. Мають бути також визначені ефективні та економічні механізми (методи) для досягнення цих цілей i відповідним чином розподілені ресурси. Підсумки та результати здійснення оборонного менеджменту мають контролюватися i оцінюватися 3 метою підвищення загальної ефективності цього процесу.
Оборонний менеджмент у державахчленах Альянсу розглядається в рамках національної політики в галузі оборони та безпеки і є процесом, який включає в себе, насамперед, державні органи, що відповідають за розроблення цієї політики та визначення бюджету оборони і безпеки.

Роль парламентів у контролі за цим процесом планування має особливе значення. Другий етап оборонного менеджменту, пов'язаний $з$ фактичним здійсненням політики та управлінням ресурсами (організація, забезпечення кадрами, керівництво i лідерство), здійснюється військовим i цивільним персоналом оборонного сектору.

Висновки. Оборонний менеджмент в державах-членах НАТО розглядається як важливий чинник управління в оборонній сфері, який дасть змогу мати: дієві та прозорі механізми демократичного контролю над оборонною діяльністю; ефективні та прозорі процедури розміщення фінансових, матеріальних ресурсів; планування в оборонній сфері; ефективне управління оборонними видатками, а також соціальноекономічними наслідками реструктуризації оборонного відомства.

Упровадження процесу оборонного менеджменту у Міністерстві оборони України відповідно до євроатлантичних принципів i підходів дасть змогу поєднати у єдиному безперервному процесі оборонне планування на основі спроможностей 3 плануванням та управлінням оборонними ресурсами, а також формуванням i виконанням державного бюджету в частині, що стосується Міністерства оборони України. 
Перспектива подальших досліджень полягає у продовженні аналізу змісту оборонного менеджменту в системі оборонного планування на основі спроможностей у державах-членах Альянсу з метою впровадження отриманого досвіду під час розроблення перспективної системи оборонного планування на основі спроможностей складових сил оборони України.

\section{ПЕРЕЛІК ВИКОРИСТАНОЇ ЛІТЕРАТУРИ}

1. Про національну безпеку України : Закон України від 21.06.2018 р. № 2469-VIII. Відомості Верховної Ради Украӥни. 2018.

2. Про рішення Ради національної безпеки i оборони України від 20 травня 2016 року “Про Стратегічний оборонний бюлетень України” : Указ Президента України від 06.06.2016 р. № 240/2016. URL: https://zakon.rada.gov.ua/ laws/show/ n0006525-16 (дата звернення: 05.12.2019).

3. Петренко А. Г. Щодо впровадження оборонного менеджменту та управління змінами в Міністерстві оборони України. Наука $і$ оборона. 2019. № 2. URL: http://nio.nuou.org.ua/ article/view/179715 (дата звернення: 07.12.2019).
4. Оборонний менеджмент: ознайомлення / за редакцією Г. Букур-Марку, Ф. Флурі, Т. Тагарева. Женева-Київ : ЦДАК та РІКК, 2010. 214 с.

5. Шаталова О.Г. Свропейський досвід стратегічного оборонного менеджменту. Уроки для України. Дніпропетровськ : НІСД, 2012. URL: https://niss.gov.ua/doslidzhennya/nacionalnabezpeka/evropeyskiy-dosvid-strategichnogooboronnogo-menedzhmentu-uroki 179715 (дата звернення: 07.12.2019).

6. Тері Макконвіль, Річард Холмс (ред.). Defence Managementin Uncertain Times. Cranfield Defence Management Series. Routledge, 2011. N 3.

7. План дій щодо партнерства 3 розбудови оборонних інституцій (Partnership Action Planon Defence Institution Building (PAP-DIB) 2004) URL: http://www.nato.int/docu/basictxt/b040607e.htm (дата звернення: 05.12.2019).

8. Полікашин В. С., Полікашин Ю. В., Поляков С. Ю. Основи управління і прийняття рішень у військовій справі : навч. посіб. Харків : НЮА України, 2003.

9 Оборонна реформа: системний підхід до оборонного менеджменту : монографія / А. Павліковський, В. Фролов, Ф. Саганюк, В. Павленко та ін. ; за ред. д-ра військ. наук А. Сиротенка. Київ : НУОУ, 2020. 306 с.

Стаття надійшла до редакційної колегії 01.01.2020

\section{Some Aspects of Implementing Defense Management in Defense Ministries of NATO Member States}

\section{Annotation}

One of the operational goals of defense reform in Ukraine is to implement the process of defense management in the defense sphere in accordance with Euro-Atlantic principles and approaches. In order to successfully achieve this goal, it is necessary to thoroughly study the experience of NATO member states in the development of defense management and its implementation in the Ministry of Defense of Ukraine.

The aim of the article is to analyze the features of the implementation of defense management used in the defense agencies of NATO member states.

The Partnership Action Plan of the Defense Institution Building (PAP-DIB) calls for strengthening the efforts of partner countries to reform and restructure their defense institutions to meet both national and international commitments.

Among the main objectives of the Action Plan were, in particular, the following:

in-depth assessment of risks to security and national defense needs, consistent with the provision and maintenance of interoperable and economically viable forces and means;

compliance with international norms and standards in the defense sector, including export controls;

effective and transparent procedures for allocating financial and material resources, planning in the defense sphere;

effective management of defense spending, as well as the socio-economic consequences of the restructuring of the Defense Ministry;

efficient and transparent personnel structures in the armed forces;

effective international cooperation and good neighborly relations on defense and security issues.

Implementation of the defense management process in the Ministry of Defense of Ukraine in accordance with Euro-Atlantic principles and approaches will allow combining in a single continuous process capacity planning based on capabilities with planning and management of defense resources, as well as formation and execution of the state budget.

Keywords: defense management; capabilities; defense planning; defense processes; budget planning; NATO. 